\title{
Evaluation of EuroSCORE II for elective isolated first time CABG patients
}

\author{
A Khan $^{1 *}$, V Srivastava ${ }^{1}$, F Mourad $^{2}$, R Richards ${ }^{1}$, A Bose $^{1}$ \\ From 23rd World Congress of the World Society of Cardio-Thoracic Surgeons \\ Split, Croatia. 12-15 September 2013
}

\section{Background}

EuroSCORE II is proposed to be a better predictor than EuroSCORE I of operative mortality in the current cohort of cardiac surgical patients. The aim of this study was to compare the performance of EuroSCORE II with the original EuroSCORE model for isolated CABG patients.

\section{Methods}

Prospectively collected data from institutional computerised database was interrogated for elective patients undergoing isolated first time CABG between May and Dec. 2013. EuroSCORE II and EuroSCORE I (additive and logistic) were calculated. The performance of each was tested using the Receiving Operating Curve analysis.

\section{Results}

Of a total of 341 patients, 286 (83.9\%) were males. The mean age was $65.85 \pm 9.9$ years. The overall 30 day mortality was $1.47 \%$ ( 5 deaths). The mean EuroSCORE II was 1.3 whereas the mean additive and logistic EuroSCORE I were 3.29 and 3.22 respectively. The area under curve (AUC) for ROC analysis were (in brackets) - for EuroSCORE II $(0.68 \pm .12)$, additive EuroSCORE I $(0.77 \pm 0.08)$ and logistic EuroSCORE I $(0.76 \pm 0.09)$.

\section{Conclusion}

All 3 scores showed moderate predictive ability as demonstrated by the AUC. Mean EuroSCORE II was however closest to the actual observed 30 day mortality.

\footnotetext{
Authors' details

'Dept of Cardiothoracic surgery, Blackpool Victoria Hospital, Blackpool, UK. ${ }^{2}$ Dept. of Cardiothoracic Surgery, Faculty of Medicine, Ain Shams University, Cairo, Egypt.
}

\footnotetext{
* Correspondence: aamirikhan@yahoo.com

'Dept of Cardiothoracic surgery, Blackpool Victoria Hospital, Blackpool, UK Full list of author information is available at the end of the article
}

Published: 11 September 2013

doi:10.1186/1749-8090-8-S1-P72

Cite this article as: Khan et al:: Evaluation of EuroSCORE II for elective isolated first time CABG patients. Journal of Cardiothoracic Surgery 2013 8(Suppl 1):P72.
Submit your next manuscript to BioMed Central and take full advantage of:

- Convenient online submission

- Thorough peer review

- No space constraints or color figure charges

- Immediate publication on acceptance

- Inclusion in PubMed, CAS, Scopus and Google Scholar

- Research which is freely available for redistribution

\section{() Biomed Central}

\section{Biomed Central}

(c) 2013 Khan et al; licensee BioMed Central Ltd. This is an Open Access article distributed under the terms of the Creative Commons Attribution License (http://creativecommons.org/licenses/by/2.0), which permits unrestricted use, distribution, and reproduction in any medium, provided the original work is properly cited. 